\title{
Moringa oleifera Lam.: Protease activity against blood coagulation cascade
}

\author{
Satish A, Sudha Sairam, Faiyaz Ahmed, Asna Urooj \\ Department of Studies in Food Science and Nutrition, University of Mysore, Mysore, Karnataka, India \\ Submitted: 01-07-2011 \\ Revised: 04-09-2011 \\ Published: 22-12-11
}

A B S T R A C T

Background: The present study evaluated the protease activity of aqueous extracts of Moringa oleifera (Moringaceae) leaf (MOL) and root (MOR). Materials and Methods: Protease activity was assayed using casein, human plasma clot and human fibrinogen as substrates. Results: Caseinolytic activity of MOL was significantly higher $(P \leq 0.05)$ than that of MOR. Similar observations were found in case of human plasma clot hydrolyzing activity, wherein MOL caused significantly higher $(P \leq 0.05)$ plasma clot hydrolysis than MOR. Zymographic techniques were used to detect proteolytic enzymes following electrophoretic separation in gels. Further, both the extracts exhibited significant procoagulant activity as reflected by a significant decrease $(P \leq 0.05)$ in recalcification time, accompanied by fibrinogenolytic and fibrinolytic activities; clotting time was decreased from $180 \pm 10 \mathrm{sec}$ to $119 \pm 8 \mathrm{sec}$ and $143 \pm 10 \mathrm{sec}$ by MOL and MOR, respectively, at a concentration of $2.5 \mathrm{mg} / \mathrm{mL}$. Fibrinogenolytic (human fibrinogen) and fibrinolytic activity (human plasma clot) was determined by sodium dodecyl sulfate-polyacrylamide gel electrophoresis (SDS-PAGE), plate method and colorimetric method. Zymographic profile indicated that both the extracts exerted their procoagulant activity by selectively hydrolyzing $A \alpha$ and $B \beta$ subunits of fibrinogen to form fibrin clot, thereby exhibiting fibrinogenolytic activity. However, prolonged incubation resulted in degradation of the formed fibrin clot, suggesting fibrinolytic like activity. Conclusions: These findings support the traditional usage of $M$. oleifera extracts for wound healing.

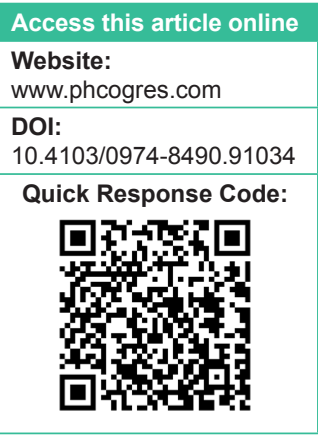

Key words: Caseinolytic, fibrinogenolytic, fibrinolytic, Moringa oleifera, procoagulant

\section{INTRODUCTION}

It is well known that proteases hydrolyze peptide bonds of proteins and they differ in their substrate specificity and ability to hydrolyze various peptide bonds. Proteases are involved in a multitude of physiological reactions from simple digestion of food proteins to highly regulated reactions such as blood cascade, complement system, and apoptosis pathways. $^{[1]}$ Several plant latex proteases are known to interfere in hemostasis as procoagulants, suggesting their unique substrate preference over other proteases. ${ }^{[2,3]}$ Cysteine proteases from the Asclepiadaceae plants latex were reported to exhibit thrombin and plasmin like activities. ${ }^{[4]}$ Proteases interfering in blood coagulation and fibrin hydrolysis have been isolated and characterized from several plant latexes. Ficin, a cysteine protease from Ficus carica, and a serine protease from Synadenium grantii

Address for correspondence:

Dr. Faiyaz Ahmed, Department of Studies in Food Science and Nutrition, University of Mysore, Mysore - 570 006, Karnataka,

India. E-mail: fayaz_ahmed09@yahoo.co.in were shown to involve in blood coagulation and fibrin hydrolysis. ${ }^{[3,5]}$

Coagulation is a complex process by which blood forms clots. It is an important part of hemostasis (the cessation of blood loss from a damaged vessel), wherein a damaged blood vessel wall is covered by a platelet and fibrincontaining clot to stop bleeding and begin repair of the damaged vessel. Disorders of coagulation can lead to an increased risk of bleeding (hemorrhage) or clotting (thrombosis). In patients with advanced liver disease, bleeding and thrombosis are dangerous complications, particularly in those who are challenged by infection or who require surgery. ${ }^{[6]}$

Moringa oleifera is a tree of the Moringaceae family, widely cultivated throughout the tropics and subtropics, and its leaves, seed pods, seeds, seed oil, roots, bark, flowers, and sap are commonly consumed as food and used in traditional medicines. Its use as an inexpensive component in foods, nutritional supplements, or medicines by patients with HIV/AIDS has been advocated by several African 
governments. ${ }^{[7]}$ It possesses anti-inflammatory, antioxidant, antimicrobial, antifertility, anticancer, antihepatotoxic and antiulcer activities. ${ }^{[8]}$

Reports have shown that the products of traditionally used plants such as Bryophyllum pinnatum and $M$. oleifera promoted healing in experimental animals. ${ }^{[9,10]}$ The M. oleifera roots and seeds are prescribed for the treatment of snake bites and scorpion stings. ${ }^{[11]} M$. oleifera leaves are also reported to have hepatoprotective activity against carbon tetrachloride-induced hepatotoxicity in rats. ${ }^{[12]}$ These plants contain a mixture of several hydrolytic enzymes, in which proteases are the key enzymes responsible for the observed pharmacological actions. Hence, the aim of the present study was to investigate the protease activity of aqueous extracts of $M$. oleifera leaf and root against the blood coagulation cascade.

\section{MATERIALS AND METHODS}

\section{Materials}

Human fibrinogen and thrombin were purchased from Sigma Aldrich, Bangalore, India. Casein was purchased from Sisco Research Laboratory, Mumbai, India. Fresh human blood samples were collected from healthy volunteers. All other chemicals and reagents used in the study were of analytical grade.

Collection of the sample and preparation of the extracts

The root and the leaves of $M$. oleifera were collected from Mysore district during November 2009, identified by Dr. Shivprasad Hudeda, and a voucher specimen was retained in the laboratory for future reference. The samples were thoroughly cleaned, dried in hot air oven at $37^{\circ} \mathrm{C}$ overnight, powdered, passed through 60 mesh sieve and stored at $4^{\circ} \mathrm{C}$ until further use. The root was cleaned, cut into small pieces, dried in the oven at $37^{\circ} \mathrm{C}$ overnight, powdered, passed through 60 mesh sieve and stored at $4^{\circ} \mathrm{C}$ until further use. Aqueous extracts were prepared by extracting the powdered samples (50 g) with distilled water $(1: 8 \mathrm{w} / \mathrm{v})$ in a mechanical shaker for $24 \mathrm{~h}$ at room temperature. The extracts were then filtered and freeze dried.

\section{Gel electrophoresis}

Sodium dodecyl sulfate-polyacrylamide gel electrophoresis (SDS-PAGE) was performed according to the method of Laemmli. ${ }^{[13]}$ Polyacrylamide gel electrophoresis (PAGE $7.5 \%$ ) under neutral conditions was carried out for aqueous extracts of leaf (MOL) and root (MOR).

\section{Caseinolytic activity}

Caseinolytic activity was assayed using denatured casein as substrate. ${ }^{[14]}$ Briefly, $0.4 \mathrm{~mL}$ casein $(2 \%)$ in $0.2 \mathrm{M}$ Tris- $\mathrm{HCl}$ buffer, $\mathrm{pH}$ 8.5, was incubated separately with different concentrations of MOL and MOR in a final volume of 1 $\mathrm{mL}$ for $2 \mathrm{~h}$ at $37^{\circ} \mathrm{C}$. The reaction was stopped by adding 1.5 $\mathrm{mL}$ of $0.44 \mathrm{M}$ trichloroacetic acid (TCA) and the mixture was allowed to stand for $30 \mathrm{~min}$. The reaction mixture was centrifuged at $1500 \mathrm{~g}$ for $15 \mathrm{~min}$. An aliquot $(1 \mathrm{~mL})$ of the supernatant was mixed with $2.5 \mathrm{~mL}$ of $0.4 \mathrm{M}$ sodium carbonate and $0.5 \mathrm{~mL}$ of Folin reagent $(1: 2, \mathrm{v} / \mathrm{v})$. The color developed was read at $660 \mathrm{~nm}$. Activity was expressed as units/h. One unit of enzyme activity was defined as the amount of enzyme required to increase the absorbance by 0.01 at $660 \mathrm{~nm} / \mathrm{h}$.

\section{Zymography}

Casein-zymography was performed according to the method of Kim et al, ${ }^{[15]}$ with SDS-PAGE $7.5 \%$ containing $0.1 \%(\mathrm{w} / \mathrm{v}$ ) casein. MOL and MOR (1-3 mg) were incubated with SDS-PAGE sample buffer without 2-mercaptoethanol for $30 \mathrm{~min}$ at $37^{\circ} \mathrm{C}$ and the samples were subjected to SDS-PAGE. After electrophoresis, the gels were washed in 2.5\% (v/v) Triton X-100 in Tris buffer, $\mathrm{pH} 7.5$, for 15 min twice and then incubated in the incubation buffer at $37^{\circ} \mathrm{C}$ for $12-24 \mathrm{~h}$ under shaking, and stained with Coomassie Brilliant Blue $\mathrm{R}$ and then destained. The area of digestion appears as clear bands against a darkly stained background where the substrate has been degraded by the enzyme.

\section{Coagulant activity}

Coagulant activity was determined according to the procedure described by Condrea et al, ${ }^{[16]}$ Fresh human blood was mixed with $0.11 \mathrm{M}$ trisodium citrate (1:9, v/v). The mixture was centrifuged for $15 \mathrm{~min}$ at $1500 \mathrm{~g}$ and the supernatant obtained was platelet poor plasma (PPP). To $300 \mu \mathrm{L}$ of PPP, $30 \mu \mathrm{L}$ of $0.01 \mathrm{M}$ Tris-HCl buffer $(\mathrm{pH}$ 7.4) was added and pre-warmed to $37^{\circ} \mathrm{C}$, following which $1 \mathrm{mg}$ of sample was added and incubated for $1 \mathrm{~min}$. The clot formation was initiated by adding $30 \mu \mathrm{L}$ of $0.25 \mathrm{M}$ $\mathrm{CaCl}_{2}$. The time taken for the formation of visible clot from the time of addition of $\mathrm{CaCl}_{2}$ was recorded. Control experiment was carried without the addition of sample.

\section{Fibrinogenolytic assay}

Fibrinogen hydrolyzing activity was estimated according to the method of Ouyang and Teng. ${ }^{[17]}$ Human fibrinogen $(50 \mu \mathrm{g})$ in $10 \mathrm{mM}$ Tris-HCl buffer, $\mathrm{pH} 7.4$, was incubated with $1 \mathrm{mg}$ MOL and MOR in a reaction volume of $40 \mu \mathrm{L}$ for $30 \mathrm{~min}$ at $37^{\circ} \mathrm{C}$. The reaction was terminated by adding $20 \mu \mathrm{L}$ of sample buffer containing $4 \%$-mercaptoethanol, $1 \mathrm{M}$ urea and 4\% SDS, and subjected to SDS-PAGE $(10 \%)$. The fibrinogen-hydrolyzing pattern was visualized by staining with Coomassie Brilliant Blue R-250. 


\section{Fibrinogen polymerization assay}

Fibrinogen polymerization assay was carried out by slightly modifying the method of Joo et al, ${ }^{[18]}$ Three milliliters of $1.2 \%$ agarose warmed to $50^{\circ} \mathrm{C}$ was mixed with $3 \mathrm{~mL}$ of $0.4 \%$ (w/v) fibrinogen dissolved in $0.1 \mathrm{M}$ Tris- $\mathrm{HCl}(\mathrm{pH}$ 7.4). Fibrinogen-agarose mixture was poured into a Petri plate and allowed to solidify for $1 \mathrm{~h}$ at room temperature. Wells of about $3 \mathrm{~mm}$ diameter were made on the plate, and $20 \mu \mathrm{L}$ of buffer containing $1 \mathrm{mg}$ of MOL and MOR was introduced into the well and incubated at $37^{\circ} \mathrm{C}$ for $2 \mathrm{~h}$. The zone of fibrin rings formed due to the polymerization of fibrinogen was observed. 0.2 unit of thrombin was used as positive control and the buffer alone served as control.

\section{Fibrinolytic activity}

\section{SDS-PAGE analysis of plasma clot hydrolysis}

The assay was carried out as described by Rajesh et al, ${ }^{[19]}$ Briefly, the washed plasma clot (cross-linked fibrin) was incubated with different amounts of MOL and MOR extracts (1-3 mg) separately in a reaction volume of $40 \mu \mathrm{L}$ containing $10 \mathrm{mM}$ Tris-HCl buffer, $\mathrm{pH} 7.4$, for $12 \mathrm{~h}$. The reaction was terminated by adding $20 \mu \mathrm{L}$ of sample buffer containing 4\% $\beta$-mercaptoethanol and $1 \mathrm{M}$ urea, boiled for $3 \mathrm{~min}$ and centrifuged to settle the debris of plasma clot. An aliquot $(20 \mu \mathrm{L})$ of the supernatant was subjected to $7.5 \%$ SDS-PAGE to analyze fibrin hydrolyzing pattern.

\section{Plasma clot hydrolyzing activity}

Plasma hydrolyzing activity was assayed according to the method by Rajesh et al, ${ }^{[19]}$ Briefly, $100 \mu \mathrm{L}$ of citrated human plasma was mixed with $30 \mu \mathrm{L}$ of $0.25 \mathrm{M} \mathrm{CaCl}_{2}$ and incubated for $2 \mathrm{~h}$ at $37^{\circ} \mathrm{C}$. The clot obtained was washed thoroughly for 5-6 times with phosphate buffered saline (PBS) and suspended in $400 \mu \mathrm{L}$ of $0.2 \mathrm{M}$ Tris-HCl buffer, $\mathrm{pH}$ 8.5. The reaction was initiated by adding varying amounts of MOL and MOR (1-5 mg) in $100 \mu \mathrm{L}$ of $10 \mathrm{mM}$ Tris- $\mathrm{HCl}$ buffer, $\mathrm{pH} 7.4$, and incubating for $2 \mathrm{~h} 30 \mathrm{~min}$ at $37^{\circ} \mathrm{C}$. The undigested clot was precipitated by adding 750 $\mu \mathrm{L}$ of $0.44 \mathrm{M}$ TCA and allowed to stand for $30 \mathrm{~min}$ and centrifuged for $15 \mathrm{~min}$ at $1500 \mathrm{~g}$. The aliquots of $0.5 \mathrm{~mL}$ supernatant were transferred to clean glass tubes, followed by the addition of $1.25 \mathrm{~mL}$ of $0.4 \mathrm{M}$ sodium carbonate and $0.25 \mathrm{~mL}$ of 1:3 diluted Folin and Ciocalteu's phenol (FC) reagent. The color developed was read at $660 \mathrm{~nm}$ after allowing the tubes to stand for $30 \mathrm{~min}$. One unit of activity is defined as the amount of enzyme required to increase the absorbance by 0.01 at $660 \mathrm{~nm} / \mathrm{h}\left(37^{\circ} \mathrm{C}\right)$.

\section{Plasma clot hydrolyzing activity (fibrinolytic activity) Plate method}

The method described by Gene et al, was followed with slight modification. ${ }^{[20]}$ A mixture consisting of $2 \mathrm{~mL}$ of healthy human plasma and $3 \mathrm{~mL}$ of $1.2 \%$ molten agarose $\left(45^{\circ} \mathrm{C}\right)$ in $10 \mathrm{mM}$ Tris- $\mathrm{HCl}$ buffer containing $0.02 \%$ sodium azide, $70 \mathrm{mM}$ (NH4) $\mathrm{SO}_{4}, 90 \mathrm{mM} \mathrm{NaCl}, 0.70 \mathrm{mM} \mathrm{MgCl}$ and $200 \mu \mathrm{L}$ of $0.2 \mathrm{M} \mathrm{CaCl}_{2}$ was poured into $10 \times 90 \mathrm{~mm}$ Petri dish and allowed to stand for $2 \mathrm{~h}$ at $27^{\circ} \mathrm{C}$. Different concentrations of MOL and MOR (1-2 mg) were placed separately on the surface of the gel matrix and incubated for $12 \mathrm{~h}$ at $27^{\circ} \mathrm{C}$. The diameters of the clear zones (plaque) were noted. $10 \mu \mathrm{L}$ of $10 \mathrm{mM}$ Tris- $\mathrm{HCl}$ buffer, $\mathrm{pH}$ 7.4, served as control.

\section{Statistical analysis}

Measurements made were mean of triplicate determinations, and wherever applicable, the data were analyzed by analysis of variance (ANOVA) followed by Tukey's multiple comparisons test for significant difference using SPSS 16.0 software.

\section{RESULTS AND DISCUSSION}

The present study showed the protease activity of aqueous extracts of $M$. oleifera leaf and root in blood coagulation cascade. Presence of proteolytic activity is one of the important characteristic features of the plant. These crude extracts were subjected to electrophoresis under SDSPAGE $(7.5 \%)$ in a non-reducing condition. In both the extracts, clearly distinguishable protein bands were resolved in gel [Figure 1].

The extracts were assessed for proteolytic activity using denatured casein as substrate. Both the extracts showed proteolytic activity in a dose-dependent manner. The leaf extract was found to exhibit significantly higher $(P \leq 0.05)$ activity compared to the root extract [Figure 2]. For further detecting the protease activity, we used the casein-zymographic technique [Figure 3]. This action is due to the presence of proteolytic

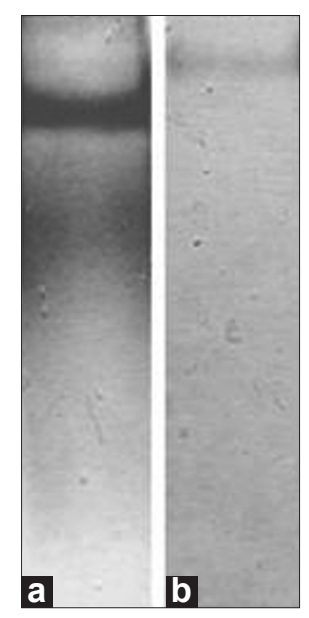

Figure 1: SDS-PAGE of MOL and MOR. $1 \mathrm{mg}$ concentration of each of the samples was loaded onto the $7.5 \%$ SDS-PAGE and electrophoresis was performed in a constant current under non-reducing condition using Tris-glycine buffer. (a) MOL and (b) MOR 


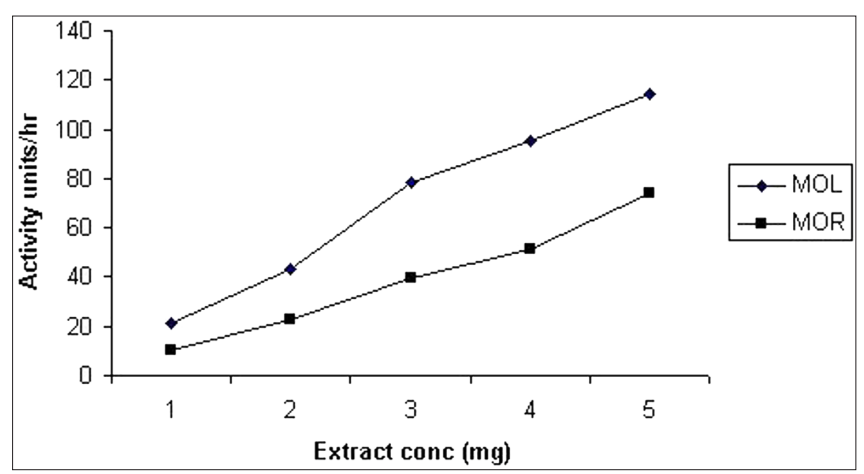

Figure 2: Caseinolytic activity of MOL and MOR extracts. One unit of enzyme activity was defined as the amount of enzyme required to increase the absorbance by 0.01 at $660 \mathrm{~nm} / \mathrm{h}$. Caseinolytic activity of MOL (- -) and MOR (- -) extracts. One milliliter of reaction mixture contained $0.4 \mathrm{~mL}$ of casein $2 \%$ in $0.2 \mathrm{M}$ Tris- $\mathrm{HCl}$ buffer, $\mathrm{pH} 8.5$, incubated with different concentrations of extracts ranging from 1 to $5 \mathrm{mg}$ for $2 \mathrm{~h}$ at $37^{\circ} \mathrm{C}$

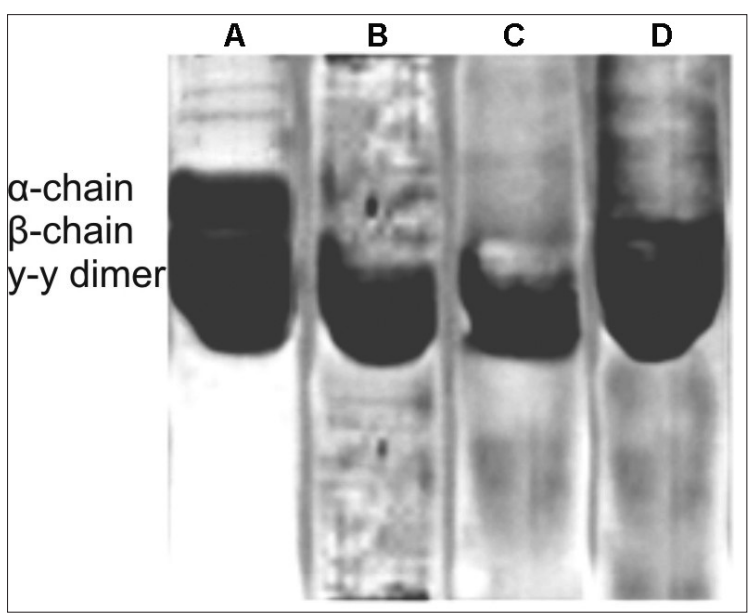

Figure 4: Electrophoresis pattern of fibrinogen by extracts. Reaction mixture of volume $40 \mu \mathrm{L}$ contained $50 \mu \mathrm{g}$ fibrinogen incubated with $1 \mathrm{mg}$

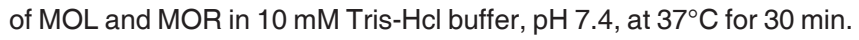
Hydrolyzing pattern of fibrinogen was monitored by $10 \%$ SDS-PAGE under reduced condition. (A) $50 \mu \mathrm{g}$ fibrinogen, (B) $50 \mu \mathrm{g}$ fibrinogen + 0.2 units thrombin, (C) $50 \mu \mathrm{g}$ fibrinogen $+1 \mathrm{mg} \mathrm{MOL}$ and (D) $50 \mu \mathrm{g}$ fibrinogen $+1 \mathrm{mg}$ MOR

enzymes and evoked further investigation on its effect on pure fibrinogen. Both the extracts hydrolyze the $A \alpha$ and $B \beta$ chains of fibrinogen subunits, but not $\gamma$ chain. Hydrolyzing pattern of fibrinogen was monitored using 10\% SDS-PAGE under reduced conditions, along with thrombin-induced fibrin clot [Figure 4]. Thrombin like enzymes hydrolyze $A \alpha$ and $B \beta$ chains of fibrinogen at the $\mathrm{N}$-terminal disulfide knot and from fibrin by releasing fibrinopeptide. ${ }^{[2]}$ Further, the fibrinogenolytic like activity of MOL and MOR was compared with known units of thrombin enzyme, using fibrinogen agar plate. Figure 5 shows the polymerization of fibrinogen by both the extracts. At the concentration of $1 \mathrm{mg}$, the diameter of the zone of fibrin rings formed due to the polymerization

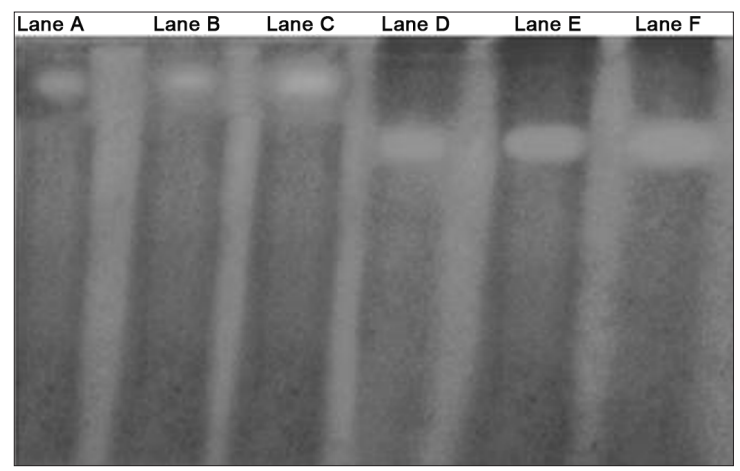

Figure 3: Protease activity of MOL and MOR by zymography method. Includes casein as a substrate copolymerized with the polyacrylamide gel, for the detection of enzyme activity. Substrate degradation products were resolved in $7.5 \%$ SDS-PAGE. Lane A, MOR (1 mg); Lane B, MOR (2 mg); Lane C, MOR (3 mg); Lane D, MOL (1 mg); Lane E, MOL (2 mg); Lane F, MOL (3 mg)

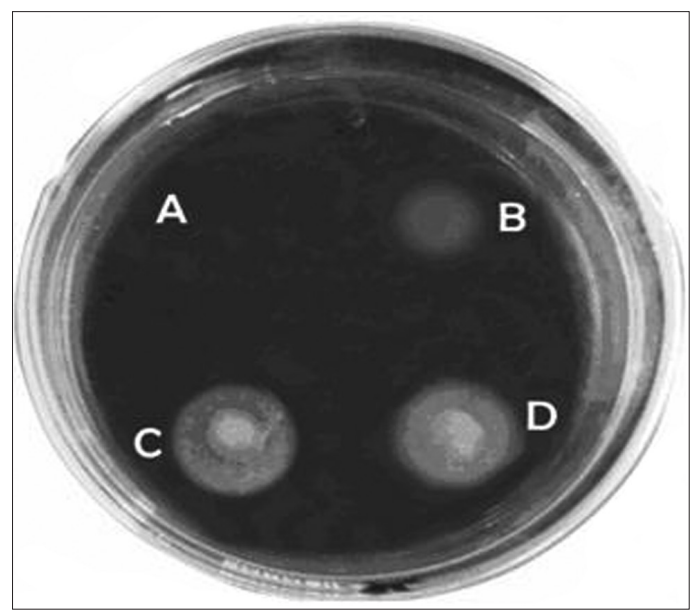

Figure 5: Fibrinogen-agarose plate assay to determine thrombin like activity of MOL and MOR. (A) Buffer alone, (B) buffer + thrombin (0.2 units), (C) buffer + $1 \mathrm{mg} \mathrm{MOL,} \mathrm{(D)} \mathrm{buffer} \mathrm{+} 1 \mathrm{mg} \mathrm{MOR}$

of fibrinogen was similar to the zone area produced by 0.2 unit of thrombin, suggesting that both the extracts have fibrinogenolytic activity. The proteolytic activity that hydrolyzes fibrinogen can either induce clot or prolong clot formation. The clot inducing or prolonging ability of these extracts was studied by determining the recalcification time of human citrated plasma. The extracts promoted clot formation after addition of $\mathrm{CaCl}_{2}$ to human citrated plasma. The induction of clot was from $180 \pm 10 \mathrm{sec}$ to $119 \pm 8$ sec in MOL, while MOR decreased the clotting time to $143 \pm 10 \mathrm{sec}$ at a concentration of $2.5 \mathrm{mg} / \mathrm{mL}$. Hydrolysis of fibrinogen by both the extracts results in the formation of fibrin clot (fibrinogenolytic activity). This study very clearly suggested that both MOL and MOR extracts exhibited procoagulant activity after addition of $\mathrm{CaCl}_{2}$ to human citrated plasma, and reduced the recalcification time in clot formation by activating the factors or by precipitating the co-factors involved in the blood coagulation cascade. 


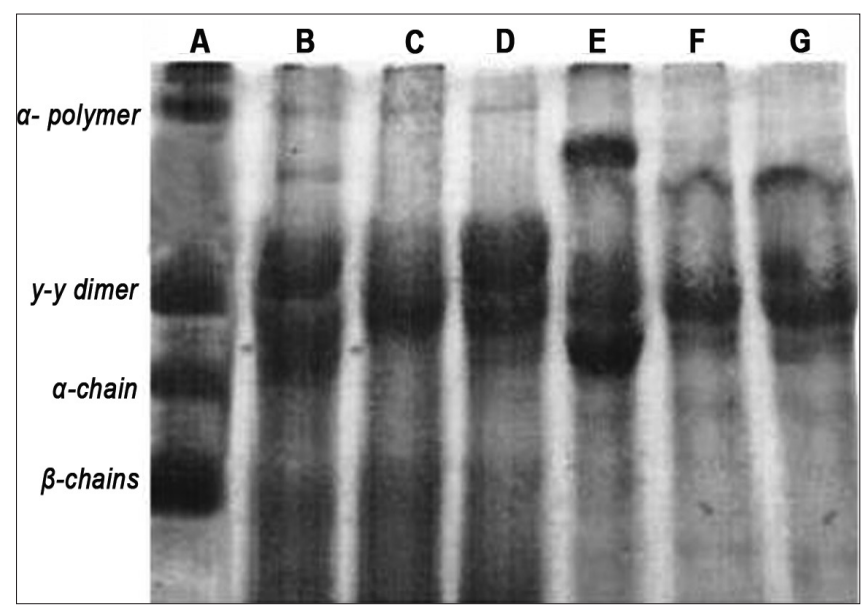

Figure 6: Dose-dependent hydrolysis of plasma clot by MOL and MOR. The washed plasma clot was incubated separately with the different concentrations of extract for $12 \mathrm{~h}$ in $40 \mu \mathrm{L}$ of $10 \mathrm{mM}$ Tris- $\mathrm{HCl}$ buffer, $\mathrm{pH} 7.4$, at $37^{\circ} \mathrm{C}$. The samples included $(\mathrm{A})$ plasma clot alone, (B) plasma clot treated with MOL I mg, (C) plasma clot with MOL 2 mg, (D) plasma clot treated with $\mathrm{MOL} 3 \mathrm{mg}$, (E) plasma clot treated with MOR I mg, (F) plasma clot treated with MOR $2 \mathrm{mg}$ and (G) plasma clot treated with MOR $3 \mathrm{mg}$

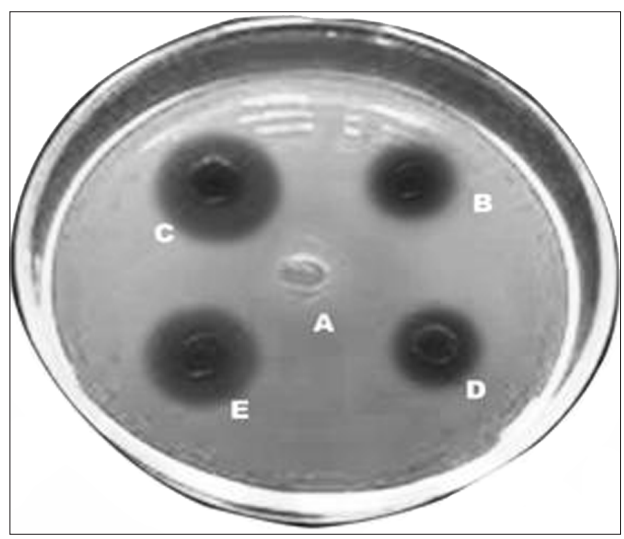

Figure 8: Fibrinolytic activity of $\mathrm{MOL}$ and MOR. The samples in 10 $\mu \mathrm{L}$ of $10 \mathrm{mM}$ Tris- $\mathrm{HCl}$ buffer, $\mathrm{pH} 7.4$, were separately placed on the surface of the gel and incubated for $12 \mathrm{~h}$ at $27^{\circ} \mathrm{C}$. (A) Buffer alone, (B) MOL $1 \mathrm{mg},(C)$ MOL $2 \mathrm{mg}$, (D) MOR $1 \mathrm{mg}$, (E) MOR $2 \mathrm{mg}$

The observed procoagulant activity/fibrinogenolytic activity might be the basis for the use of extracts to stop bleeding by traditional healers.

Besides fibrinogenolytic activity, the extracts exhibited plasma clot hydrolyzing properties on prolonged incubation, resulting in degradation of the formed fibrin clot, which suggests fibrinolytic like activity by the hydrolysis of only few subunits of $\alpha$-polymer, $\alpha$-chains, $\beta$-chains of crude fibrin clot in a dose-dependent manner. To substantiate these clot hydrolyzing properties, the hydrolyzed products of fibrin clots were analyzed on SDS-PAGE 7.5\% [Figure 6] under reducing condition, colorimetric method

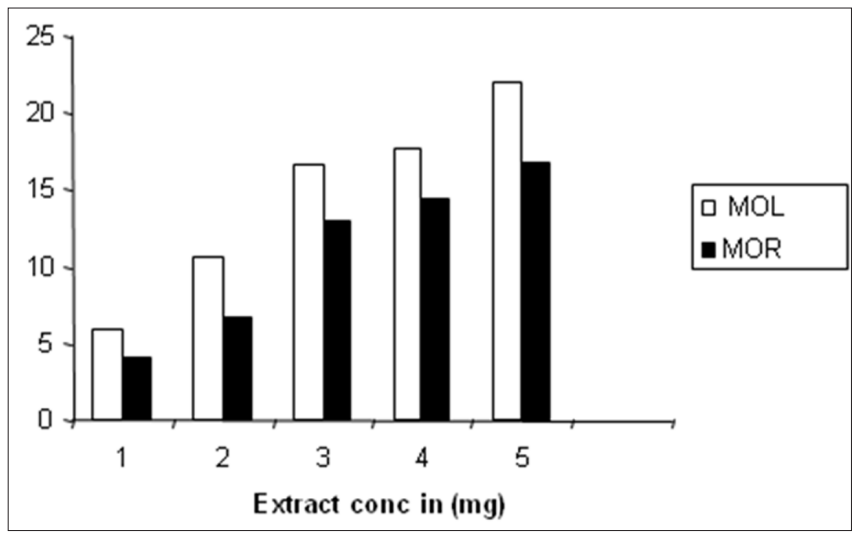

Figure 7: Concentration-dependent hydrolysis of human plasma clot. One unit of enzyme activity was defined as the amount of enzyme required to increase the absorbance by 0.01 at $660 \mathrm{~nm} / \mathrm{h}$

and plate method [Figures 7 and 8]. Eventually, blood clots are reorganized and resorbed by a process termed fibrinolysis. The main enzyme responsible for this process (plasmin) is regulated by various activators and inhibitors. Plasmin is generated by proteolytic cleavage of plasminogen, a plasma protein synthesized in the liver. This cleavage is catalyzed by tissue plasminogen activator (t-PA), which is synthesized and secreted by endothelium. Plasmin proteolytically cleaves fibrin into fibrin degradation products that inhibit excessive fibrin formation and hemostatic plug, facilitating wound healing. ${ }^{[2]}$ However, extracts of leaf (MOL) and root (MOR) exhibited a mixture of both fibrinogenolytic and fibrinolytic activities. Present data suggested the dual action of crude extracts, i.e. both fibrinogenolytic and fibrinolytic activities, might be due to the presence of thrombin and plasmin like enzymes or a single enzyme responsible for the dual action.

\section{CONCLUSION}

The study provides scientific validation for the use of M. oleifera in traditional medicine as an anticoagulant. The results suggest the involvement/presence of thrombin and plasmin like enzymes. Further studies are needed to understand the mechanism of action. Hence, attempts are underway to purify both thrombin and plasmin like proteases from $M$. oleifera leaf and root to promote their pharmacological utilization.

\section{ACKNOWLEDGMENT}

The authors acknowledge the funding assistance received from University Grant Commission in the Special Assistance Program, New Delhi, India (NO.F.640/1/DRS/2007(SAP-I). 


\section{REFERENCES}

1. Konno K, Hirayama C, Masatoshi N, Tateishi K, Tamura Y, Hattori $\mathrm{M}$, et al. Papain protects papaya trees from herbivorous insects: Role of cysteine proteases in latex. Plant J 2004;37:370-8.

2. Rajesh R, Shivaprasad HV, Gowda RC, Nataraju A, Dhananjaya BL, Vishwanath BS. Comparative study on plant latex proteases and their involvement in hemostasis: A special emphasis on clot inducing and dissolving properties. Planta Med 2007;73:1061-7.

3. Richter G, Hans PS, Friedrich D, Peter L. Activation and inactivation of human factor $\mathrm{X}$ by proteases derived from Ficus carica. Br J Haematol 2002;119:1042-51.

4. Shivaprasad HV, Riyaz M, Kumar VR, Dharmappa KK, Tarannum $\mathrm{S}$, Siddesha JM. Cysteine proteases from the Asclepiadaceae plants latex exhibited thrombin and plasmin like activities. J Thromb Thrombolysis 2008;28:304-8.

5. Rajesh R, Gowda CD, Nataraju A, Dhananjaya BL. Purification and characterization of a $34-\mathrm{kDa}$, heat stable glycoprotein from Synadenium grantii latex: Action on human fibrinogen and fibrin clot. Biochimie 2006;88:1313-22.

6. Mehta $A B$. Management of coagulopathy in patients with liver disease undergoing surgical intervention. Indian J Gastroenterol 2006;25:19-21.

7. Anwar F, Latif S, Ashraf M, Gilani AH. Moringa oleifera: A food plant with multiple medicinal uses. Phytother Res 2007;21:1725.

8. Goyal BR, Agrawal BB, Goyal RK. Phyto-Pharmacology of Moringa oleifera Lam: An overview. Nat Prod Rad 2007;6:34753.

9. Khan M, Patil PA, Shobha JC. Influence of Bryophyllum pinnatum (Lam.) leaf extract on wound healing in albino rats. J Nat Rem 2004;4:41-6.

10. Hukkeri VI, Nagathan CV, Karadi RV, Patil BS. Antipyretic and wound healing activities of Moringa oleifera Lam. in rats. Indian J Pharm Sci 2006;68:124-6.

11. Satyavati GV, Gupta AK. Medicinal plants of India. Indian Council of Medical Research. 1987;2:272-8.

12. Selvakumar D, Natarajan P. Hepato-Protective activity of Moringa oleifera Lam. leaves in carbon tetrachloride induced hepato-toxicity in albino rats. Pharmacogn Mag 2008;4:97-8.
13. Laemmli UK. Cleavage of structural proteins during the assembly of head of bacteriophage T4. Nature 1970;227:680-5.

14. Murata J, Satake M, Suzuki T. Studies on snake venom. XII. Distribution of proteinase activities among Japanese and Formosan snake venoms. J Biochem 1963;53:431-43.

15. Kim SH, Choi NS, Lee WY. Fibrin zymography: A direct analysis of fibrinolytic enzymes on gels. Anal Biochem 1998;263:115-6.

16. Condrea E, Yang CC, Rosenberg P. Anticoagulant activity and plasma phophatidylserine hydrolysis by snake venom phospholipase A2. Thromb Haemost 1983;49:151-7.

17. Ouyang C, Teng CM. Fibrinogenolytic enzymes of Trimeresurus mucrosqua- matus Venom. Biochim Biophys Acta 1976;420: 298-308.

18. Joo HS, Park GC, Cho WR, Tak E, Paik SR, Chang CS. Purification and characterization of a prothrombin-activating protease from Nephila ciavata. Toxicon 2002;40:289-96.

19. Rajesh R, Gowda CD, Nataraju A, Dhananjaya BL, Kemparaju $\mathrm{K}$, Vishwanath BS. Procoagulant activity of Calotropis gigantea latex associated with fibrin (ogen) olytic activity. Toxicon 2005;46:84-92.

20. Gene A, Roy G, Rojas JM, Gutierrez S, Cerdas L. Comparative study on coagulant, defibrinating, fibrinolytic and fibrinogenolytic activities of Costa Rican crotaline snake venoms and their neutralization by a polyvalent antivenom. Toxicon 1989;27: 841-8.

21. Komori $Y$, Sugihara H, Tu AT. Specificity of haemorrhagic proteinase from Crotalus atrox (Western diamond back rattle snake) venom. Biochim Biophys Acta 1985;829:127-30.

22. Lijnen HR. Matrix metalloprotenases and their cellular fibrinolytic activity. Biochemistry (Mosc) 2002;67:92-8.

Cite this article as: Satish A, Sairam S, Ahmed F, Urooj A. Moringa oleifera Lam.: Protease activity against blood coagulation cascade. Phcog Res 2012;4:44-9

Source of Support: University Grant Commission in the Special Assistance Program, New Delhi, India (NO.F.640/1/DRS/2007(SAP-I), Conflict of Interest: None declared.

\section{Dispatch and return notification by E-mail}

The journal now sends email notification to its members on dispatch of a print issue. The notification is sent to those members who have provided their email address to the association/journal office. The email alerts you about an outdated address and return of issue due to incomplete/incorrect address.

If you wish to receive such email notification, please send your email along with the membership number and full mailing address to the editorial office by email. 